\title{
弱光条件に対する水稲の個体光合成の 調節機構と根の活力の役割*
}

\author{
津 野 幸人・山口武視 \\ (鳥取大学農学部) \\ 昭和 63 年 7 月 29 日受理
}

\begin{abstract}
要 旨：水稲 3 品種をポット栽培し, 分げつ期から登熟初期にかけて, 期間を変えて遮光処理（50\%）およ び標高 $303 \mathrm{~m}$ の山間部で生育させる“山あげ”処理を行い，対照区と対比して水稲の弱光条件に対する調節 機構を個体光合成能力の面から解析し,さらに根の呼吸速度と光合成との関連性を明らかにした。 分げつ期の処理では茥数が $17 〜 43 \%$ 減少し，個体当り葉面積（F）が著しく隇少した。しかし，穂数へ の影響が少ない時期の処理では，葉身長，比葉面積の增大により，Fは 13〜 54\% 増加した。

処理による乾物生産量の平均抑制率は $30.3 \%$ で，N吸収量のそれは $3.7 \%$ であった。このため，体内 濃度が上昇し，その反映として葉身および根部の $\mathrm{N} \%$ が上昇した．葉身 $\mathrm{N} \%$ の昇は，総光合成速度を高

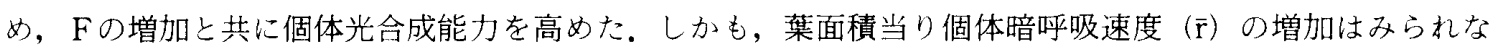
かった。この $\overline{\mathrm{r}}$ につて葉身 $\mathrm{N} \%$ と茎重/葉面積 ( $\mathrm{C} / \mathrm{F})$ 比の 2 要因を用いて重回帰分析を行った結果, 重 相関係数 $\mathrm{R}=0.823 * *$ が得られた。 $\mathrm{N} \%$ は $\mathrm{r}$ を增加させるが， $\mathrm{F}$ の増加は $\mathrm{C} / \mathrm{F}$ 值を対照区より低い值とし， これが $\overline{\mathrm{r}}$ の增大を強く打ち消す方向に作用した。

根の呼吸速度（R）について根部 N\%と C/F 比で重回帰分析を行ったところ高い重相関係数 $\left(0.817^{* *}\right)$

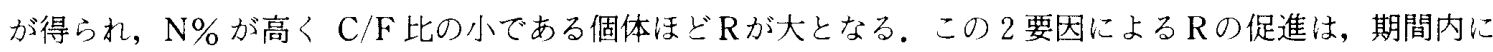
增加した $N$ 吸収量 $(\Delta \mathrm{N})$ 上乾物量 $(\Delta \mathrm{W})$ の比 $(\Delta \mathrm{N} / \Delta \mathrm{W})$ を高め, 体内 $\mathrm{N}$ 濃度を高く保つ方向に作用し た. キーワード：暗呼吸速度, 乾物生産量, 光合成能力, 遮光, 水稲, 窒素吸収量, 根の呼吸速度.
\end{abstract}

\begin{abstract}
Adaptive Regulation of Photosynthesis in Rice Plant to Weak Light Condition and the Contribution of Root Activity to Regulation Mechanism : Yukindo Tsuno and Takeshi YamaGuchi (Faculty of Agriculture, Tottori University, Koyama, Tottori 680, Japan)

Abstract : Three cultivars of rice plants were grown in pots in a shading frame of $50 \%$ light intensity and on shadowed place at high altitude of $303 \mathrm{~m}$ in hillside during the different period from tillering to early ripening stage in order to compare the photosynthetic activity, root respiration and nitrogen absorption with those of control plants.

After the period of tiller number determined, the shading-treatment promoted leaf area developing through the both ways of increase in leaf length and specific leaf area ; it could contribute to enhancement of the photosynthesis per plant. Also photosynthetic rate per leaf area in the treated plant was higher than in the control plant due to higher N\% in the leaf. Dry matter production was more depressed than nitrogen absorption by the shading, i.e., decreased rates of the former and the latter in average were $30.3 \%$ and $3.7 \%$, respectively.

The result of a multiple regression analysis for dark respiration of plant per leaf area $(\bar{r})$ showed that $\bar{r}$ had a high positive correlation to $\mathrm{N} \%$ in leaf and high negative correlation to $\mathrm{C} / \mathrm{F}$ ratio ( $\mathrm{C}$ : Stem weight, $\mathrm{F}$ : Leaf area), therefore, $\overline{\mathrm{r}}$ of treated plants did not increase owing to the low $\mathrm{C} / \mathrm{F}$ value.

Multiple regression analysis between root respiration and two factors, $\mathrm{N} \%$ in root and $\mathrm{C} / \mathrm{F}$ ratio, showed high correlation coefficient as $\mathrm{R}=0.817^{* *}$ : the root respiration of the shaded plant had higher rate than that of control. The amount of nitrogen absorbed during treated period was sustained with the root respiration and the dry matter production.

Key words : Dark respiration, Dry matter production, Nitrogen absorption, Photosynthesis, Rice plant, Root respiration, Shading.
\end{abstract}

各地域の気象統計のうえで降水分布に年変動が大 きいのと同様に，日射量の分布も年によって大きな 変動を示し，長期間の罢天は稲作期間にしばしば出 現する。ことに，中小河川水系内に分布する水田 は, 谷底部あるいは山腹に位置し, 山の稜線によっ

* 大要は第 177 回講演会（昭和 59 年 4 月）にお いて発表。
て日射が遮られるために，平野部の水田に比較して 常に少ない日射量のもとで水稲は生育している。こ うした弱光のもとでの水稲の生育は概して徒長, 軟 弱となることが経験的に知られており，中山間地向 けの品種は低温に対する抵抗力はもちろんである が, 弱光条件に刘しても順応する能力が要求され る. 
水稲が弱光条件下におかれたとき, 葉肉組織の厚 さが薄くなる4,11)ことは知られている。また，光合 成機能に関しては，遮光された水稲葉の光合成速度 が低下するという報告8,11)もあるが，逆に光合成速 度が高まるという報告 ${ }^{12,199}$ もある。一般に，植物 が弱光条件下で育った場合に示す光合成特性の変化 は, 光飽和点の低下 ${ }^{1,2,7)}$ ならびに強光下での光合成 速度の低下 ${ }^{3,7}$ が知られている。ところが，遮光条 件下に扔いて，水稲はその光合成能力の調節を通し て順応していることが清水・津野12)によって指摘さ れ，その機構については，葉身の窒素濃度の増加に よって純光合成能力の向上がみられることが明らか にされている.しかし, 光合成能力について生育の 各段階での調節能力とか，低温と弱光が複合された 場合の実態，あるいは品種間差の有無，さらには調 節能力の発現における根部の活力の役割などは不明 であるので，これらの諸点を明らかにすべく以下の 実験を行ない，いくつかの知見を得たので報告す る.

\section{材料および方法}

鳥取県平坦部に広く分布している日本晴（育成場 所: 愛知農試), 山間部で安定な作柄を示すアキヒ カリ (同：青森農試)，良質米として当地方化普及 しつつあるコシヒカリ（同：福井農試）の 3 品種を 材料とした。
上記 3 品種を 1982 年 5 月 10 日にペーパーポット へ播種，葉齢 5.6 葉苗を 6 月 9 日にポット(径 15 $\mathrm{cm}$, 深さ $17.5 \mathrm{~cm})$ に1本づつ移植した，基肥は 高度化成肥料で 3 要素各 $1 \mathrm{~g}$ 施した。このポットを 鳥取大学湖山農場（標高 $5 \mathrm{~m}$ ） と鳥取市安蔵（標高 $303 \mathrm{~m} ）$ の水田内に埋めた（各品種とも 1 処理に 30 ポットを供試).

湖山農場では遮光区を設定し, 各品種 30 個体に 遮光率 $50 \%$ の寒冷紗布で作った枠を，7月 6 日 (葉桧 11.7）上り7月 27 日まで（S-I）かぶせた。 ついで，8月1日より登熟初期まで（S-II），さら に，7月6日より登熟初期まで (S-III) と逐次新た な 30 個体に遮光処理をおこなった。また，山地の 安蔵の水田で 6 月 10 日より 7 月 28 日まで生育させ た山あげ処理（Y-I ），抢よび一定期間を低地の湖 山に置いたのちに安蔵に運び上げるという山あげ処 理（Y-II）を行った。山あげ期間は，第 1 表のと おり品種によって終了日を変えた。なお，安蔵水田 は別の調査によって, 湖山よりも稲作期間の平均気 温で $2.2^{\circ} \mathrm{C}$ 低く, 晴天日の日射量が $25 \%$ 少ないこ とが確められている。

光合成作用の測定は, 温度制御の出来る $1.5 \mathrm{~m}^{3}$ の箱内に，個体用同化箱を持ち込み，流気法によっ て個体光合成を測定した。光源は 6 個の陽光ランプ で上方より照射し，同化箱の側面に鏡を置いて光む らを少なくした。照度は東京光学機械（株）SPI-

第 1 表 遮光 $(\mathrm{S})$, 山あげ $(\mathrm{Y})$ 処理の期間, 処理終了時の穂数抢よび地上部乾物重 $\left(\mathrm{g} \cdot \mathrm{plant}^{-1}\right)$ と $\mathrm{N}$ 含有量 $\left(\mathrm{mg} \cdot\right.$ plant $\left.^{-1}\right)$ ならびに処理による増減 $(\%)$.

\begin{tabular}{|c|c|c|c|c|c|c|c|c|c|c|c|}
\hline \multirow{2}{*}{ 品 種 } & \multirow{2}{*}{ 処 } & \multirow{2}{*}{ 理 } & 処理月日 & \multirow{2}{*}{$\begin{array}{l}\text { 処理 } \\
\text { 日数 }\end{array}$} & \multirow{2}{*}{$\begin{array}{l}\text { 出穗日 } \\
\text { 月・日 }\end{array}$} & \multicolumn{2}{|c|}{ 株当り穂数 (荎数) } & \multicolumn{2}{|c|}{ 乾物重 } & \multicolumn{2}{|c|}{$\mathrm{N}$ 含有量 } \\
\hline & & & 始一終 & & & 対 照 & 処 理 & 対 照 & 増 減 & 対 照 & 増減 \\
\hline \multirow{5}{*}{$\begin{array}{l}P \\
\neq \\
\text { t } \\
\text { 力 } \\
\text { リ }\end{array}$} & S-I & $(\mathbf{A})$ & $7.6 \sim 7.27$ & 21 & $(8.9)$ & $(44.2)$ & $(30.6)$ & 29.2 & -45 & 586 & -37 \\
\hline & S-II & $(\Delta)$ & $8.1 \sim 8.21$ & 21 & 8.9 & 25.1 & 25.7 & 60.7 & -26 & 903 & -19 \\
\hline & S-III & $(\Delta)$ & $7.6 \sim 8.21$ & 47 & 8.9 & 25.1 & 20.9 & 60.7 & -27 & 903 & -25 \\
\hline & $Y \cdot I$ & $(\triangle)$ & $6.10 \sim 7.28$ & 48 & - & $(44.2)$ & $(30.4)$ & 29.2 & -55 & 586 & -29 \\
\hline & Y-II & $(\Delta)$ & $8.3 \sim 8.21$ & 19 & 8.10 & 25.1 & 25.2 & 60.7 & -14 & 903 & -9 \\
\hline \multirow{5}{*}{$\begin{array}{l}コ \\
\vdots \\
\text { 岁 } \\
\text { 力 } \\
\text { J }\end{array}$} & S-I & (回) & $7.6 \sim 7.27$ & 21 & $(8.21)$ & $(44.6)$ & $(37.0)$ & 26.8 & -21 & 713 & -20 \\
\hline & S-II & $(\bullet)$ & $8.1 \sim 8.31$ & 30 & 8.21 & 29.3 & 27.3 & 65.9 & -25 & 654 & +32 \\
\hline & S-III & (D) & $7.6 \sim 8.31$ & 57 & 8.21 & 29.3 & 25.3 & 65.9 & -22 & 654 & -4 \\
\hline & Y-I & (口) & $6.10 \sim 7.28$ & 48 & - & $(44.6)$ & $(30.2)$ & 26.8 & -60 & 713 & -46 \\
\hline & Y-II & $(\otimes)$ & $8.3 \sim 8.31$ & 29 & 8.21 & 29.3 & 23.0 & 65.9 & -21 & 654 & +12 \\
\hline \multirow{5}{*}{$\begin{array}{l}\text { 杲 } \\
\text { 晴 }\end{array}$} & S-I & 10 & $7.6 \sim 7.27$ & 21 & $(8.25)$ & $(49.0)$ & $(33.0)$ & 24.0 & -34 & 690 & -30 \\
\hline & S-II & $(\odot)$ & $8.1 \sim 9.11$ & 42 & 8.27 & 29.9 & 23.8 & 64.4 & -17 & 830 & +81 \\
\hline & S-III & (D) & $7.6 \sim 9.11$ & 68 & 8.28 & 29.9 & 24.8 & 64.4 & -8 & 830 & +74 \\
\hline & Y.I & (D) & $6.10 \sim 7.28$ & 48 & - & $(49.0)$ & $(28.1)$ & 24.0 & -63 & 690 & -54 \\
\hline & Y-II & $(\otimes)$ & $8.3 \sim 9.11$ & 40 & 8.28 & 29.9 & 28.2 & 64.4 & -17 & 830 & +19 \\
\hline
\end{tabular}

注. 出穂日の（）内は無処理のもの. 穂数の（）は茎数.

各品種とも白記号はIの対照区を示し，II, IIIのそれには棒線を付した。 
第 2 表 処理終了時の比葉面積 $\left(\mathrm{SLA}: \mathrm{cm}^{2} \cdot \mathrm{g}^{-1}\right)$ と葉面積 $\left(\mathrm{F}: \mathrm{dm}^{2} \cdot \mathrm{plant}^{-1}\right)$.

\begin{tabular}{|c|c|c|c|c|c|c|c|c|c|c|c|c|}
\hline \multirow{2}{*}{ 処理 } & \multicolumn{4}{|c|}{ アキヒカリ } & \multicolumn{4}{|c|}{ コシヒカリ } & \multicolumn{4}{|c|}{ 日 本 晴 } \\
\hline & SLA & $\%$ & $F$ & $\%$ & SLA & $\%$ & $\mathrm{~F}$ & $\%$ & SLA & $\%$ & $\mathrm{~F}$ & $\%$ \\
\hline 対照 & 199 & 100 & 21.5 & 100 & 186 & 100 & 21.6 & 100 & 208 & 100 & 21.8 & 100 \\
\hline S-I & 245 & 123 & 22.6 & 105 & 205 & 110 & 19.9 & 92 & 201 & 97 & 14.9 & 68 \\
\hline Y-I & 217 & 109 & 12.1 & 56 & 201 & 108 & 9.6 & 44 & 230 & 111 & 8.7 & 40 \\
\hline 対照 & 202 & 100 & 14.9 & 100 & 177 & 100 & 13.6 & 100 & 190 & 100 & 17.3 & 100 \\
\hline S-II & 193 & 96 & 16.8 & 113 & 179 & 101 & 16.5 & 121 & 214 & 113 & 22.2 & 128 \\
\hline S-III & 256 & 127 & 20.5 & 138 & 184 & 104 & 15.7 & 115 & 247 & 130 & 26.6 & 154 \\
\hline Y-II & 209 & 103 & 18.5 & 124 & 178 & 101 & 17.5 & 129 & 222 & 117 & 26.1 & 151 \\
\hline
\end{tabular}

注. 以下の表の処理記号は第 1 表と同じ.

71 形光電池照度計を用いて葉層の中心の高さで測 定した。光合成の測定温度は $25^{\circ} \mathrm{C}$ に固定した。ま た，本装置の最高照度は株元で $50 \mathrm{klx}$ であって， 照度を低下させる場合は光源と同化箱との間に白紙 を挿入し，その枚数によって調節した。穂は常に同 化箱に入れる直前に切除し, 出穂前の值との比較を 容易にした。

光合成の測定を終了した個体は，ただちに暗呼吸 を測定し，その後で根を洗い出して各茎を分離した 後に, 刃物で茎基部を縦に割り, 上部 3 節から発生 した根と，それ以下の節の根とに区別した。そし て, 水を振り切り, 硬質プラスチック製の網上に細 長く広げて，これを円筒状の呼吸測定箱に入れ，一 端より外気を送り，他端の小孔より排出する空気の 一部を赤外線炭酸ガス分析計に導いて, 放出する $\mathrm{CO}_{2}$ 量を計測し, これを根の呼吸量とみなして根 の活力を表示する形質として取扱った。

測定材料は乾燥させた後に粉末として，七ミ・ミ クロケルダール法で乾物重当たりの $\mathrm{N}$ 定量した。 乾物重の調查はすべて 10 個体についておこなった。

\section{結果および考察}

\section{1. 形態的変化を通しての弱光条件への調節}

すべての供試個体は順調に生育し，圑場条件での 生長量とほほ同程度か, やや大きめの生長量を示し た。遮光および山あげ処理による生育状態の変化を 第 1 表でみると, 日本晴では出穂が 3 日程度遅延し ているが，他の 2 品種はほとんぞ影響を受けていな い. 主稈葉数は, アキヒカリの処理 S-IIIが 1 葉隇 少した。長期間遮光した処理S-IIIは 3 品種とも穗 数が 14〜17\% 減少した。山あげ処理 Y-I では茎数 の減少が全品種にみられたが, 処理 Y-IIで穂数が 減ったのはコシヒカリだけであった。すべての品種 で, 遮光処理によって草丈が伸び, その程度は日本
第 3 表 遮光処理による葉身長 $(\mathrm{cm})$ の変化.

\begin{tabular}{cccccc}
\hline 品 種 & 処理 & 13葉 & 14 葉 & 15葉 & 16葉 \\
\hline \multirow{2}{*}{ アキヒカリ } & 対照 & 40.4 & 32.8 & 20.7 & 12.1 \\
& S-III & $45.6^{* *}$ & 38.1 & 20.8 & - \\
\hline \multirow{2}{*}{ コシヒカリ } & 対照 & 42.0 & 39.8 & 31.0 & 22.9 \\
& S-III & 45.6 & 44.2 & 32.3 & 21.0 \\
\hline \multirow{2}{*}{ 日 晴 } & 対照 & 36.7 & 34.9 & 36.3 & 24.7 \\
& S-III & 39.4 & $47.6^{* *}$ & $44.6^{* *}$ & 25.4 \\
\hline
\end{tabular}

注. ${ }^{* *}: 1 \%$ 水準で有意. 処理開始時の葉歯 11.7 .

晴が最も大であった。

一般に弱光条件におかれると水稲は葉が薄くなる ことが知られている (SLA) を, 処理終了時のものについて第 2 表に示 した，処理S-Iによる21日間の遮光ではアキヒカ リ、コシヒカリの SLA が大となった。処理 S-IIで は日本晴, 処理 S-IIIでは日本晴, アキヒカリの SLAの増大が著しいが, コシヒカリはほとんど影 響を受けていない。しかし, 遮光期間中に伸長した 葉の葉身は長くなる傾向を示した(第 3 表). 穂数 (茎数), SLA および葉身長に処理の影響を受けて 個体当たり葉面積は変化したのであるが, 第 2 表に みられるとおり処理 S- I, Y-I では茎数減のため 個体の葉面積はほとんどの区で減少している。とこ ろが処理 S-II, III, Y-IIでは個体葉面積は処理に より増加し, なかでも日本晴は処理 S-III, Y-IIに おいて対照区よりも約 $50 \%$ も葉面積が増えた。

処理 S-IIIにおける弱光条件への形態的調節とし て, 葉身長の増大は 13,14 葉で全品種にみられる。 また, SLA の増大には品種間差があり, 平坦部む きの日本晴は長期の遮光および山あげによって SLA が増大しやすい傾向が顕著であるといえる.

\section{2. 弱光条件への光合成能力の調節}

遮光処理抢よび山あげ処理終了時に個体光合成を 種々の照度 (I) のもとで測定して光-光合成曲線 
を求め，対照区のそれと比較したのが第 1 図の左側 および中央の図である。第 1 図右側の図は，戸外自 然光のもとでの光一光合成曲線である。これらの図 は個体光合成をその個体の葉面積で除して，単位葉 面積当たりの光合成速度（Po）として表示してあ るが，すべての処理区は対照区よりも明らかに純光 合成速度が高まっていることがわかる。

本実験では，個体光合成を測定しているので，第 1 図のごとく表示した純光合成速度は, 非光合成器 官の呼吸によって，幾分かは引下げられた值となっ ている。そこで, 個体純光合成速度に個体暗呼吸速 度を加えて個体総光合成速度を算出し，これを個体 葉面積で除して, 葉面積当たり総光合成速度 $(\mathrm{Pg})$ として表示した，そして，光-総光合成関係を全測 定 21 例について求めたところ, その曲線は,

$\mathrm{Pg}=\mathrm{aI}^{\mathrm{b}} \ldots \ldots \ldots \ldots \ldots \ldots$ (1) (但し， a , b は定数) という一般式で表現でき，それぞれの曲線の決定係 数は $\mathrm{r}^{2}=0.935$ 以上であった。

これはあくまでも処理が光一光合成関係に如何な る影響を及ぼすかを検討する目的で，各区の代表株 1 個体について求めたものであって, 光合成速度そ のものを区間で比較するためには試料数が余りにも 少ない.

そこで，光合成速度と正の相関を持つ葉身 $\mathrm{N}$ 含有 率に着目し，雨者の関係から処理の影響を評価しよ うとした。本実験での葉身 N含有率と総光合成速度 (Pg) との関係を作図してみると第 2 図のとおりで あって，両者の間には広く認められているとおりの 比例的関係（ただしここの場合は対数回帰式によ る）が成立した。また，Pg と葉面積当たり $\mathrm{N}$ 含量 との間にも第 2 図と同様の傾向があり，この場合の 相関係数は $\mathrm{r}=0.784^{* *}$ (有意水準 $1 \%$ で有意）であ
つた.

それぞれの処理終了時における葉身 $\mathrm{N}$ 含有率は第 4 表に示したと抢りであって，処理 S-Iのコシヒ カリ以外はすべての処理において葉身 N含有率は高 まっているが，その程度は一様ではなく，葉身 $\mathrm{N}$ 含 有率の増加程度の大である区ほど $\mathrm{Pg}$ の増加が大で あることが第 2 図の関係より指摘できる、葉身 $\mathrm{N}$ 含 有率 (NL) は地上部 $\mathrm{N}$ 含有率 $(\mathrm{Nt})$ を反映したも ので，両者の間には次式で示される関係がある。

$\mathrm{NL}=1.112(\mathrm{Nt})+0.916\left(\mathrm{r}=0.906^{* *}\right) \cdots \cdots(2)$

いま，第 2 図の関係式に第 4 表の葉身 $\mathrm{N}$ 含有率を 代入して各区のPg を求め, これより葉面積当たり 暗呼吸速度（ $\overrightarrow{\mathrm{r}})$ を差引いて純光合成速度 $(\mathrm{Po})$ と し，これらをまとめて第 5 表に示した，同表で処理 S-IによってPg が顕著に増加したのはアキヒカリだ けである、ところが，処理 S-II，IIIおよびY-I， IIでは 3 品種すべてに扎い Pg の増加がみられ る。これらは葉身 $\mathrm{N}$ 含有率の上昇に対応したもので ある。すでに，第 2 表で処理S-II，IIIにおいて個 体葉面積が著しく増加したことを指摘した。これは 群落としての最適葉面積の範囲までならば, 葉面積 の増加は群落光合成の向上に役立つはずであり，そ の範囲内であれば個体葉面積の増加も調節機能の発 現として評価すべきであろう。

そこで，第 5 表の $\mathrm{Pg}$ と $\mathrm{r}$ 乾物重調查個体の平 均葉面積を乗じて個体総光合成速度と個体暗呼吸速 度を算出して第 6 表にかかげた。第 6 表をみると， コシヒカリ，日本晴は処理 S - I, Y - Iにより個体 総光合成速度は減少している。これと較べてアキヒ カリは処理 S - I により増加し, 処理Y-Iによる減 少程度も少ない.この傾向は中山間部むけの品種の 特性として望ましいものであろう。つぎに，処理 $\mathrm{S}$

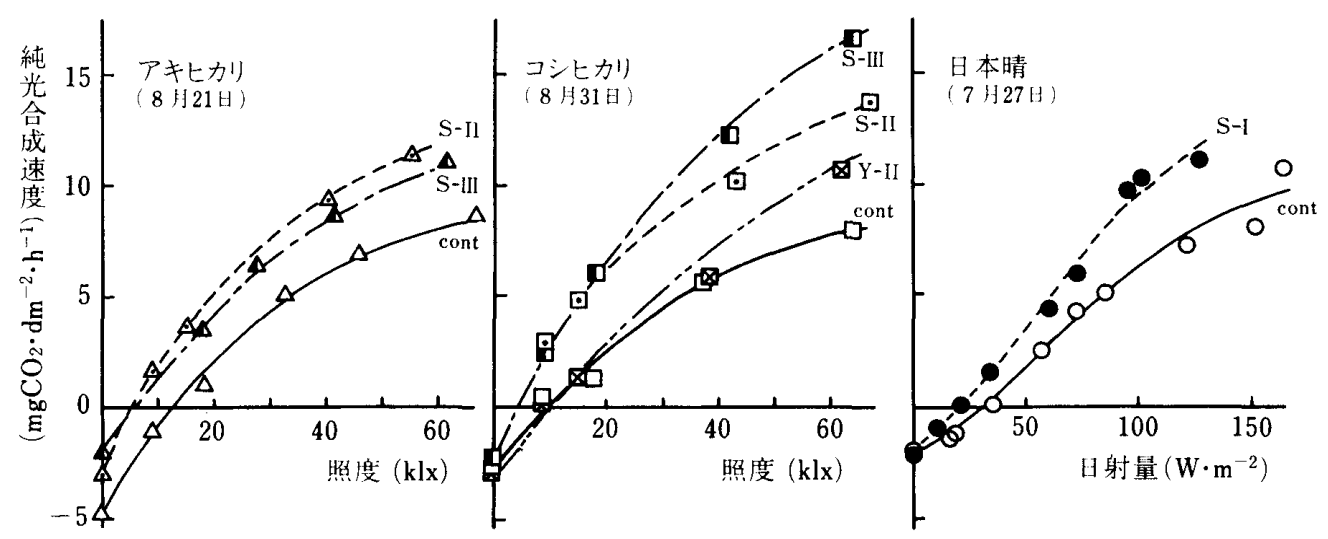

第 1 図 照度と純光合成速度との関係（左，中央図）ならびに戸外での日射〜純光合成関係（右図）。 注）処理記号は第 1 表と同じ. contは無処理を示す。 


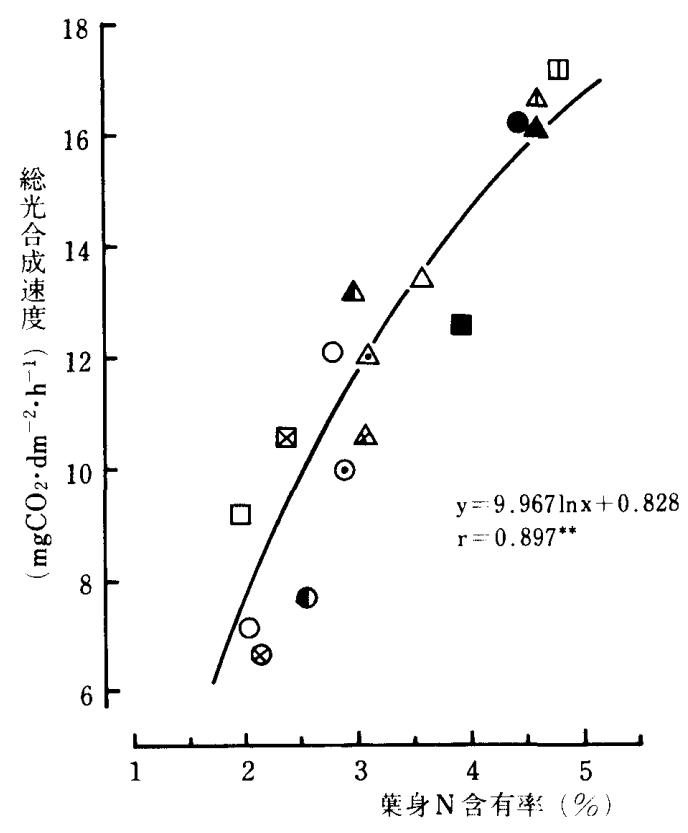

第 2 図葉身 $\mathrm{N}$ 含有率と照度 $50 \mathrm{klx}$ における総 光合成速度との関係.

注）以下の図中の記号は第 1 表と同じ. $\mathrm{r}$ : 相関係数。**：有意水準 $1 \%$ で有意。 以下同じ。
-II, IIIおよびY-IIをみると, すべてが個体総光合 成速度を増加させて打り, 明らかに弱光条件に対す る光合成能力の調節作用が認められる.

他方，乾物生産に対して負の要因である個体暗呼 吸速度の変化を第 6 表で検討すると, 処理 Y - I, S-I, IIIでは減少するが, 処理 Y-II, S-IIではか えって増加している区もある。これは，個体葉面積 のほかに第 5 表にある葉面積当たり個体暗呼吸速度

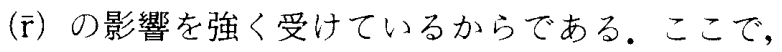
処理が $\overline{\mathrm{r}}$ に及ぼす影響をみると，処理 S-Iは的に はほとんど影響を与えないが，処理 Y - I ではr が 大となり, 処理 S-II, IIIの多くはr いる(第 5 表)。この様な変動を統一的に説明する ために $\overline{\mathrm{r}}$ を目的変数とし, 第 4 表の葉身 $\mathrm{N}$ 含有率 (NL) と第 5 表の茎重/葉面積比 $(\mathrm{C} / \mathrm{F})$ を説明変 数として重回帰分析をおこなった。結果は次のとお りである。

$$
\overline{\mathrm{r}}=1.536(\mathrm{NL})+1.510(\mathrm{C} / \mathrm{F})-4.063
$$

上式の決定係数は $\mathrm{R}^{2}=0.677$ であり， $\mathrm{r}$ は上記 2 変数で約 $70 \%$ が説明できる。つまり，葉身 $\mathrm{N}$ 含有

第 4 表 処理終了時に扔ける窒素濃度 (対乾物\%)，根の呼吸速度 $\left(\mathrm{R}: \mathrm{mgCO}_{2} \cdot \mathrm{gDW}^{-1} \cdot \mathrm{h}^{-1}, 25^{\circ} \mathrm{C}\right)$ ならびに根 量 $\left(\mathrm{RW}: \mathrm{mgDW} \cdot \mathrm{stem}^{-1}\right)$.

\begin{tabular}{|c|c|c|c|c|c|c|c|c|c|c|c|c|}
\hline \multirow{3}{*}{ 処理 } & \multicolumn{4}{|c|}{ アキヒカリ } & \multicolumn{4}{|c|}{ コシヒカリ } & \multicolumn{4}{|c|}{ 日 本 晴 } \\
\hline & \multicolumn{2}{|c|}{ 窒素濃度 } & \multirow{2}{*}{$\mathrm{R}$} & \multirow{2}{*}{ RW } & \multicolumn{2}{|c|}{ 窒素濃度 } & \multirow{2}{*}{$\mathrm{R}$} & \multirow{2}{*}{ RW } & \multicolumn{2}{|c|}{ 窒素濃度 } & \multirow{2}{*}{$\mathrm{R}$} & \multirow{2}{*}{ RW } \\
\hline & 地上部 & 葉身 & & & 地上部 & 葉身 & & & 地上部 & 葉身 & & \\
\hline 対照 & 2.30 & 3.51 & 1.55 & 69 & 2.66 & 3.95 & 2.23 & 65 & 2.77 & 4.26 & 2.44 & 110 \\
\hline S-I & 2.95 & 4.56 & 1.53 & 60 & 2.60 & 3.90 & 2.63 & 57 & 3.04 & 4.43 & 2.97 & 83 \\
\hline Y-I & 3.23 & 4.69 & 2.92 & 90 & 3.53 & 4.86 & 3.01 & 43 & 3.65 & 5.18 & - & 66 \\
\hline 対照 & 1.47 & 2.72 & 0.78 & 145 & 1.16 & 1.93 & 0.76 & 178 & 1.16 & 2.02 & 0.45 & 150 \\
\hline S-II & 1.63 & 3.07 & 0.78 & 152 & 1.80 & 2.70 & 1.20 & 189 & 1.82 & 2.85 & 1.11 & 115 \\
\hline S-III & 1.53 & 2.92 & 1.37 & 137 & 1.34 & 2.43 & 1.49 & 121 & 1.62 & 2.58 & 1.07 & 119 \\
\hline Y-II & 1.55 & 3.06 & 1.25 & 124 & 1.32 & 2.32 & 0.93 & 177 & 1.80 & 2.15 & 0.99 & 155 \\
\hline
\end{tabular}

第 5 表 処理終了時におりる個体の葉面積当たり総光合成速度 $(\mathrm{Pg})$, 暗呼吸速度 $(\overline{\mathrm{r}})$, 純光合成速度 $(\mathrm{Po})$ ならび に茥重/葉面積比 $(\mathrm{C} / \mathrm{F})$.

\begin{tabular}{|c|c|c|c|c|c|c|c|c|c|c|c|c|}
\hline \multirow{2}{*}{ 処理 } & \multicolumn{4}{|c|}{ アキヒかり } & \multicolumn{4}{|c|}{ コシヒカリ } & \multicolumn{4}{|c|}{ 日 本 晴 } \\
\hline & $\mathrm{Pg}$ & $\overline{\mathrm{r}}$ & Po & $\mathrm{C} / \mathrm{F}$ & $\mathrm{Pg}$ & $\bar{r}$ & Po & $\mathrm{C} / \mathrm{F}$ & $\mathrm{Pg}$ & $\overline{\mathrm{r}}$ & Po & $\mathrm{C} / \mathrm{F}$ \\
\hline 対照 & 13.3 & 3.4 & 9.9 & 1.09 & 14.5 & 2.2 & 12.3 & 0.67 & 15.3 & 3.2 & 12.1 & 0.74 \\
\hline S.I & 16.0 & 3.1 & 12.9 & 0.55 & 14.4 & 2.1 & 12.3 & 0.66 & 15.7 & 3.5 & 12.2 & 0.71 \\
\hline Y-I & 16.2 & 5.0 & 11.2 & 0.58 & 16.6 & 4.1 & 12.5 & 0.62 & 17.2 & 5.6 & 11.6 & 0.57 \\
\hline 対照 & 10.8 & 4.4 & 6.4 & 2.03 & 7.4 & 3.0 & 4.4 & 2.93 & 7.8 & 2.8 & 5.0 & 3.12 \\
\hline S-II & 12.0 & 3.1 & 8.9 & 1.34 & 10.7 & 3.1 & 7.6 & 1.42 & 11.3 & 1.4 & 9.9 & 1.03 \\
\hline S-III & 11.5 & 1.8 & 9.7 & 0.96 & 9.7 & 2.2 & 7.5 & 1.70 & 10.3 & 1.4 & 8.9 & 0.99 \\
\hline Y-II & 12.0 & 3.0 & 9.0 & 1.79 & 9.2 & 3.3 & 5.9 & 2.07 & 8.5 & 1.6 & 6.9 & 1.55 \\
\hline
\end{tabular}

注. $\mathrm{Pg}, \mathrm{Po}: \mathrm{mgCO}_{2} \cdot \mathrm{dm}^{-2} \cdot \mathrm{h}^{-1}, 50 \mathrm{klx} \cdot \overline{\mathrm{r}}: \mathrm{mgCO}_{2} \cdot \mathrm{dm}^{-2} \cdot \mathrm{h}^{-1}, 25^{\circ} \mathrm{C} . \mathrm{C} / \mathrm{F}: \mathrm{g} \cdot \mathrm{dm}^{-2} . \mathrm{Pg}$ は第 2 図の式と 第 4 表の葉身 $\mathrm{N} \%$ で算出. 
率が高ければテを引き上げるが， $\mathrm{C} / \mathrm{F}$ が小となる とその効果を打ち消すのである。この関係を確認す るために, 葉身 $\mathrm{N}$ 含有率が $2.6 \sim 3.1 \%$ の範囲にあ

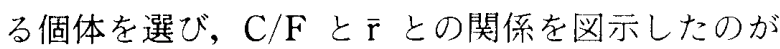
第 3 図であって，両者は正比例の関係にあることが わかった。遮光処理により葉身 N含有率が増加して も，それにより個体当たり葉面積が増大したとき は， $\mathrm{C} / \mathrm{F}$ 比の低下により葉面積当たり個体暗呼吸 速度を引き下げる方向に作用する。逆に言えば，下 葉が枯れ上がった稲は非光合成器官の暗呼吸量が相 対的に増大して，乾物生産に不利な体制となる。な を， $\mathrm{C} / \mathrm{F}$ 比が純同化率の重要な要素であることは，

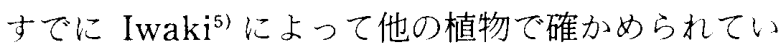
る.

さて，水稲に遮光処理を扔こなった場合に光合成 速度が増加あるいは低下するといった相反する現象

第 6 表 個体当り総光合成速度 $(\mathrm{P})$ と個体当り暗 呼吸速度 (DR)。

\begin{tabular}{|c|c|c|c|c|c|c|}
\hline \multirow{2}{*}{ 処理 } & \multicolumn{2}{|c|}{ アキヒカリ } & \multicolumn{2}{|c|}{ コシヒカリ } & \multicolumn{2}{|c|}{ 日 本 } \\
\hline & $\mathrm{P}$ & DR & $\mathrm{P}$ & DR & $\mathrm{P}$ & DR \\
\hline 対照 & 286.0 & 73.1 & 313.2 & 47.5 & 333.5 & 69.8 \\
\hline S-I & 361.6 & 70.1 & 286.6 & 41.8 & 233.9 & 52.2 \\
\hline Y-I & 196.0 & 60.5 & 159.4 & 39.4 & 149.6 & 48.7 \\
\hline 対照 & 160.9 & 65.6 & 100.6 & 40.8 & 134.9 & 48.4 \\
\hline S-II & 201.6 & 52.1 & 176.6 & 51.2 & 250.9 & 31.1 \\
\hline S-III & 235.8 & 36.9 & 152.3 & 34.5 & 274.0 & 37.2 \\
\hline Y-II & 222.0 & 55.5 & 161.0 & 57.8 & 221.9 & 41.8 \\
\hline
\end{tabular}

注. $\mathrm{P}: \mathrm{mgCO}_{2} \cdot$ plant $^{-1} \cdot \mathrm{h}^{-1}, 50 \mathrm{klx}$.

$\mathrm{DR}: \mathrm{mgCO}_{2} \cdot$ plant $^{-1} \cdot \mathrm{h}^{-1}, 25^{\circ} \mathrm{C}$.

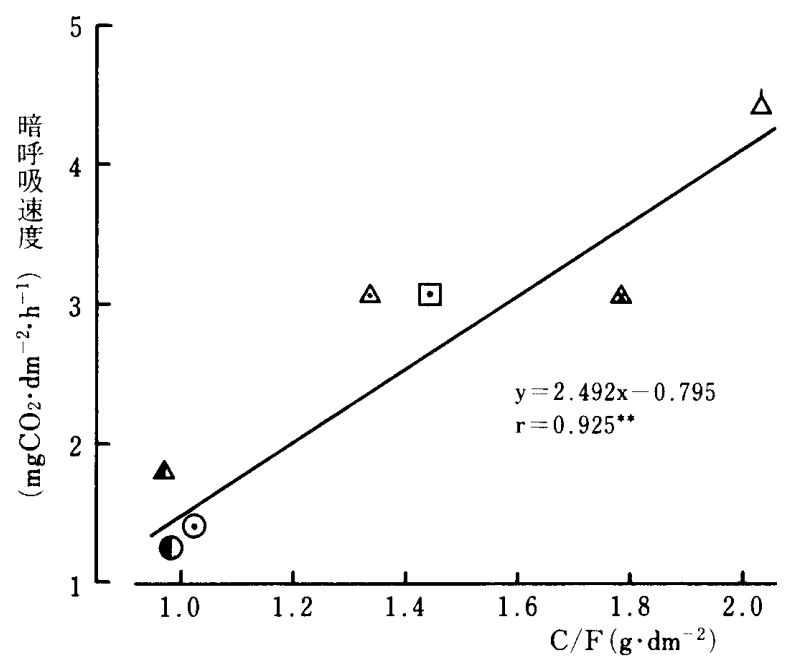

第 3 図葉身 $\mathrm{N}$ 含有率が $2.6 \sim 3.1 \%$ 個体に扔 ける $\mathrm{C} / \mathrm{F}$ 比と葉面積当たり暗呼吸速度との 関係。
は，葉身の $\mathrm{N}$ 含有率あるいは葉面積当たり $\mathrm{N}$ 含有量 の増減に対応するものであることを明らかにしてき たが，つぎに検討を加えておかねばならぬのは光補 償点の問題である。そこで，照度 $50 \mathrm{klx} に$ における $\mathrm{Pg}$ と $10 \mathrm{klx}$ という低照度に扔ける Pg との関係を みると，そ机㳉第 4 図のと抢りであって，高照度に 扔いて高いPg を示すものほど，低照度側でも高い $\mathrm{Pg}$ が得られる。光補償点は, 葉面積当たり暗呼吸 速度（第 5 表）により，それぞれが異なるので，一 定した值をとらないのであるが，第1図の光〜光合 成曲線よりみて, 高照度側で高い純光合成速度であ るものほど，光補償点は低いということが指摘でき る.

\section{3. 体内 $\mathrm{N}$ 濃度の決定機構と根の呼吸速度}

遮光によって水稲の体内 $\mathrm{N}$ 濃度が上昇するという 現象は多くの研究者によって認められてい $3^{9 \sim 13,15)}$.すでに第 4 表で示したと扔り，本実験に おいても同様のことが知られた。この体内 $\mathrm{N} \%$ が 上昇する機構は，第 1 表にかかげた乾物重と $\mathrm{N}$ 含有 量との関係で容易に説明がつく。つまり, 遮光・山 あげによって乾物重は全区平均で $30.3 \%$ 隇少した のに対し， $\mathrm{N}$ 含有量の隇少は全区平均で $3.7 \%$ に しかすぎない。なかには，遮光により $\mathrm{N}$ 含量が増加 した区もある。この遮光の影響を受ける程度が乾物 生産と $\mathrm{N}$ 吸収に扔いて大きく異なり，前者を上り強 く抑制するために，体内 $\mathrm{N}$ 濃度が上昇したのであ 了.

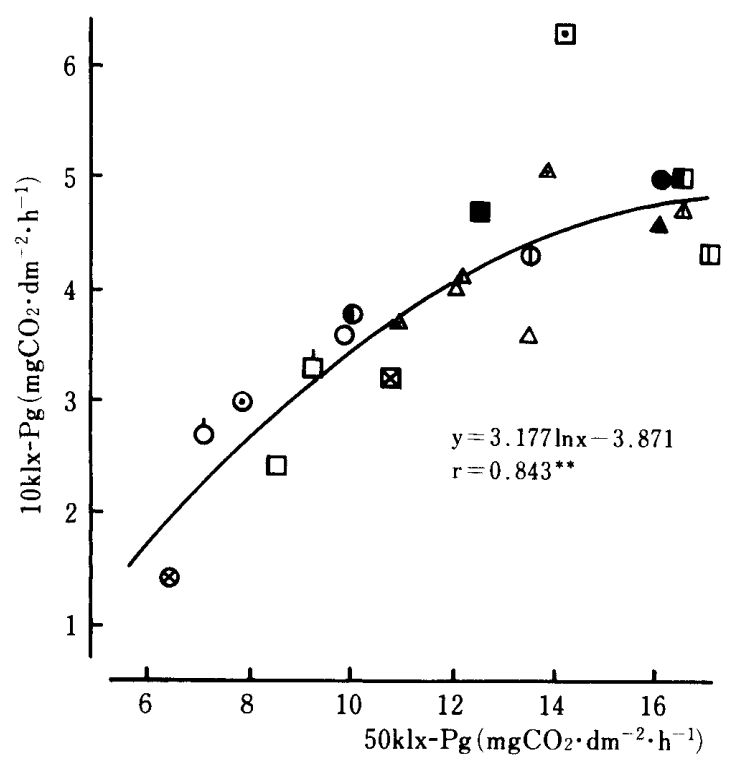

第 4 図 照度 $50 \mathrm{klx}$ にお ける総光合成速度 $(50$ $\mathrm{klx}-\mathrm{Pg}$ ）と照度 $10 \mathrm{klx}$ における総光合成速 度 $(10 \mathrm{klx}-\mathrm{Pg})$ との関係。 


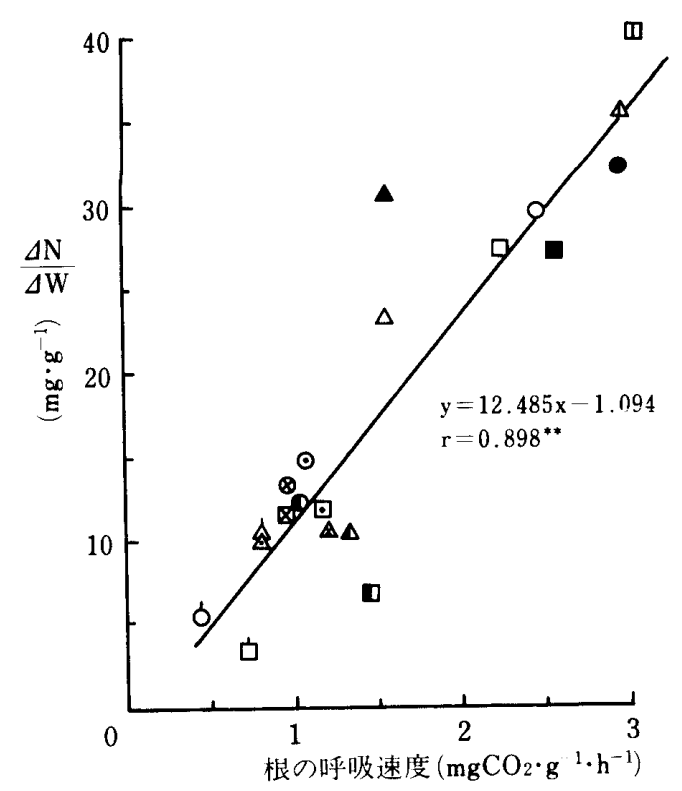

第 5 図処理終了時に扔ける根の呼吸速度と処理 期間内の乾物生産量当たり $\mathrm{N}$ 吸収量 $(\Delta \mathrm{N} /$ $\Delta W)$ との関係.

ここで問題としなくてはならぬのは体内N濃度の 上昇程度である。稲体 $\mathrm{N}$ 濃度の決定機構を定量的に 解明するために，つぎの考え方に従って論を進め た.すなわち, 遮光開始時の乾物重と $\mathrm{N}$ 含有量をそ れぞれW， $\mathrm{N}$ とすば，遮光終了時の $\mathrm{N}$ 濃度は $(N+\Delta N) /(W+\Delta W)$ (但し, 遮光期間内の乾物重 増加量 $(\Delta \mathrm{W})$ および $\mathrm{N}$ 増加量 $(\Delta \mathrm{N}))$ で決定され る。そこで， $\Delta \mathrm{N} / \Delta \mathrm{W}$ 比に関与する要因を検討し た結果，第 5 図が得られた。ところで，同図の根の 呼吸速度は，上位節根と下位節根との加重平均值で あって, 個体の根総量の平均呼吸速度を示してお り，以下に述べる呼吸速度も同様である。

第 5 図で $\Delta \mathrm{N} / \Delta \mathrm{W}$ 比は処理終了時の根の呼吸速 度 $(\mathrm{R})$ と高い正の相関を持って㧈り, 同図の式㳉 次のごとくなる.

$$
\Delta \mathrm{N}=\Delta \mathrm{W} \quad(12.485 \mathrm{R}-1.094) \cdots
$$

ある期間内の $\mathrm{N}$ 吸収量は，同期間における乾物生 産量が多ければ，また，その期間内の根の呼吸速度 が高ければ，それらに比例して多くなるというのが (4) 式の内容である.また， $\Delta \mathrm{N}$ が等しくともWの 大きい個体よりもWが小さい個体の方が稲体N濃度 がより多く增加することは言うまでもない。著者 ら ${ }^{18)}$ は既述の方法で測定した根の呼吸速度が根の 活力を包括的に表現するものとして取扱ってきた。 そして, 根の呼吸速度と吸水との関係を通じて水稲 光合成の高温低下現象を解析した，本論文では根の 呼吸速度が乾物増加量と共䡉してN吸収に関与する
局面をとらえることができた、すなわち，植物によ る無機虽分吸収は，呼吸から提供されるエネルギー によって行われることは多くの実験によって明らか にされている。この養分吸収が継続的にかつ活発に 進行するためには, 地上部に送られて各器官内で蓄 積あるいは機能的な物質に合成されなければならな い.

（4）式における $\Delta W$ の内容は稲体の生長と物質 の蓄積であって， $\Delta \mathrm{W}$ が大であることは蛋白合成 の規模が大であることを示している．したがって， 土壌からの $\mathrm{N}$ 供給が制限因子とならない限りは，根 の呼吸速度が高く $\Delta \mathrm{W}$ が大であるときに $\mathrm{N}$ 吸収量 は多くなると考えられる。

つぎに，稲体 $\mathrm{N}$ 濃度と根の呼吸速度との関連につ いて解析をすすめたい。遮光が根の形態や呼吸に及 ぼす影響をみた研究を概観すると，川田・鄭的は根 の直径, 根毛密度の減少, Tatsumi and Kono ${ }^{14)}$ は 根重，呼吸， $\mathrm{N}$ 吸収ともに低下を認めている。ま た，遮光により $\mathrm{N}$ 吸収は上位根で増大するが，中・ 下位根で減少すること㬏，根の $\alpha^{-ナ フ チ ル ア ミ ~}$

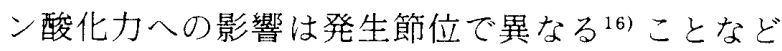
が知られている。本実験では，第 4 表のとおり遮 光，山あげ処理により根の呼吸速度はすべての処理 区が対照区よりも高い。すでに，著者ら ${ }^{(8)}$ は根の 呼吸速度（R）と葉身 N\%(NL) との間に高い正 の相関のあることを報告しているが，この関係を第 4 表の数值で再確認すると, 相関係数 $\mathrm{r}=0.879^{* *}$ $(\mathrm{NL}=1.017 \mathrm{R}+1.646)$ が得られた。この関係は 葉身 $\mathrm{N}$ 含有率と根部 $\mathrm{N}$ 含有率との高い相関17)を介在 して成立するものであって，本実験では，地上部稲 体 $\mathrm{N} \%$ と葉身 $\mathrm{N} \%$ との間に $\mathrm{r}=0.906^{* *}$ ，また，前 者と根部 $N \%$ との間にも $\mathrm{r}=0.848^{* *}$ という高い相 関係数が算出された。著者ら ${ }^{18)}$ 注水稲根の呼吸速 度は根の $\mathrm{N} \%(\mathrm{Nr})$ と根の全糖含有率とが関与する という結果を得ている。そして，登熟中期において は根の全糖含有率は 1 茎当たりの光合成能力を示す ところのN含有量/茎と高い正の相関関係のあるこ とを指摘した。本実験では全糖含有率が分析されて いない。そこで, 茥重と葉面積との相対的関係を示 すところの $\mathrm{C} / \mathrm{F}$ 比と $\mathrm{Nr}$ とを説明変数として，根 の呼吸速度（R）を目的変数とする重回㷌分析をお こなった。その結果 $0.781^{* *}$ という重相関係数がえ られ，重回帰式はつぎのとおりであった。

$\mathrm{R}=0.840(\mathrm{Nr})-0.682(\mathrm{C} / \mathrm{F})+1.488 \cdots$

なお，両説明変数間の相関係数はー0.450**であ 


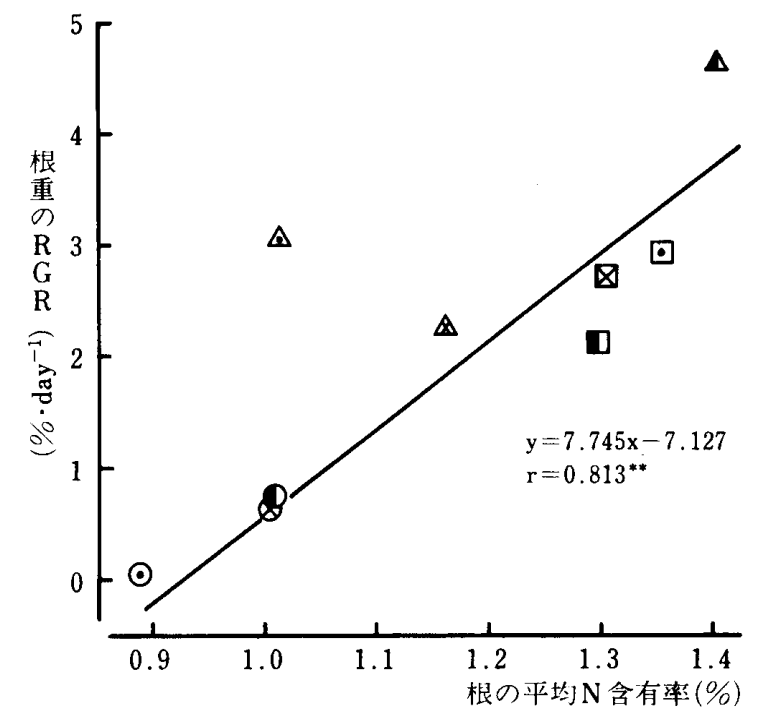

第 6 図 処理期間内の根の平均 $\mathrm{N}$ 含有率と同期間 内の根重の相対生長率 (RGR) との関係.

った．上の回帰分析を処理S-II, III, Y-IIに限っ ておこなうとC/Fのウエイトが高まって重相関係 数は $0.817^{* *}$ に高まる。ここで第 5 表にかかげた $\mathrm{C} / \mathrm{F}$ についていえば，この值の時期および区間の 変動は稲体 $\mathrm{N} \%$ で説明することができ, 両者の間 の相関係数は $\mathrm{r}=-0.812^{* *}$ であった。つまり, 体 内 N\%の高いものほど茎重に対する葉面積を多く 保持することができた。これらの諸結果を踏まえ て, 根の呼吸速度の高い稲の印象を具体化すれば, “茎部が徒長しないで葉色が濃く，下葉の枯れ上り の少ない”ということになる.

根の $\mathrm{N}$ 含有率は, 根の呼吸に関与するとともに, 根の量的生長にも関与しているという事実も明らか となった。すなわち, 第 6 図は処理期間内の根の平 均 $\mathrm{N} \%$ と処理期間内に扔ける根重の相対生長率と の関係を示したものであって両者の間に高い正の相 関関係があり, 根の $\mathrm{N} \%$ の高いものほど相対生長 率は高い.ただし, 第 6 図の処理は RGR の算出デ ーターを有するS-II, III, Y-IIであって, 各品種 の生育段階は穂ばらみ期から登熟初期までである。

\section{4. 弱光条件に対する乾物生産能力の調節}

本実験では水稲に $50 \%$ 程度の弱光条件を遮光に よって与える処理と, 平均気温で $2.2^{\circ} \mathrm{C}$ の低温, 晴 天日射量の $25 \%$ 減少という山間部水田で水稲を生 育させる処理（山あげ）をおこない，それぞれ対照 区と比較して形態とガス交換機能の両面から調節能 力を明らかにしてきた．得られた緒結果を総合して 乾物生産能力に関連づけてみると第 7 図の如くにま とめることができる．本項ではこの図の流れに従っ

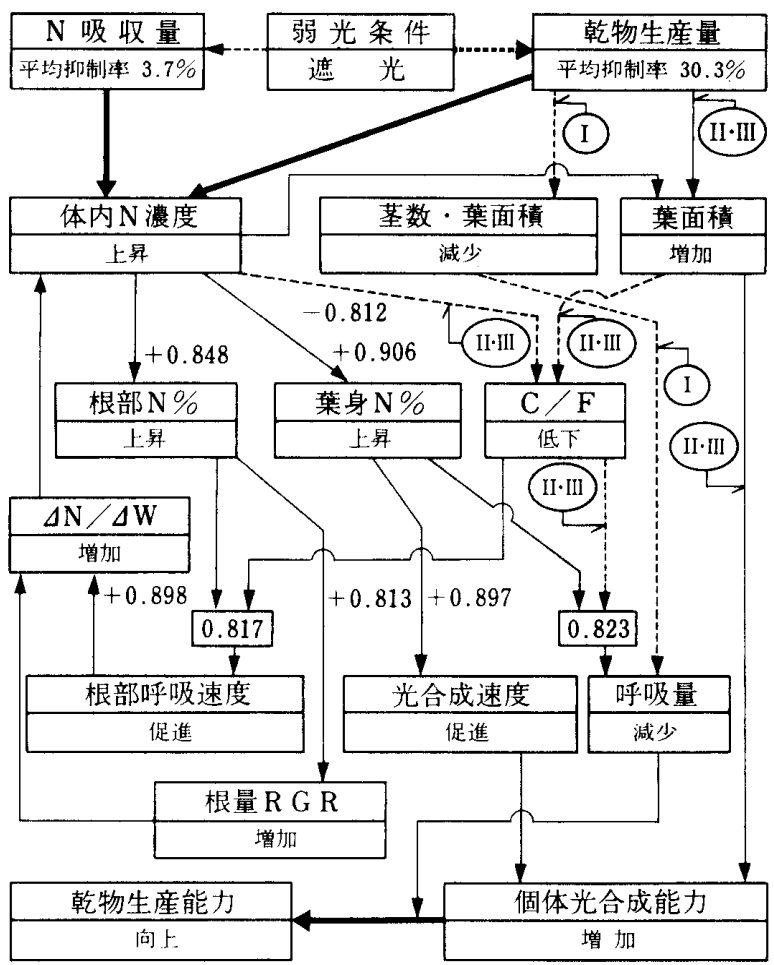

第 7 図 分げつ期より登熟初期における水稲の弱 光条件への調節機構.

注）十，一を付した数字は相関係数，の内の 数字は重相関係数。-フラスに作用, …..マイナスに作用，I，II，IIIは第 1 表の 処理（時期）に対応.

て, 弱光条件に対する乾物生産能力の調節機能の獲 得過程を明らかにしてみたい.

上述した 2 種の処理の稲体に及ぼす影響で, 共通 して認められるのは体内N濃度の上昇である(第 4 表)。これは弱光条件が乾物生産を強く抑制するの に対して，N吸収の抑制は軽度あるいは促進する (第 1 表) からであって，この体内 $\mathrm{N}$ 濃度上昇を基 軸として形態的あるいは機能的調節が発動する。分 げつ期における遮光（S-I）は茎数の減少を招き (第 1 表), 個体葉面積の著しい隇少をもたらすが, 比葉面積の増加によって幾分なりともその減少を補 償する (第 2 表).ところが, 穂数への影響の少な い処理 S-II, III, Y-IIでは, SLA の増大と葉身 が長くなることにより個体葉面積は対照区よりもか えつて大となる (第 2 表)。そして, 葉身 $\mathrm{N} \%$ 高 まりは光合成速度を高め(第 2 図), 個体葉面積の 增大とあい伴って個体光合成能力を向上させた（第 6 表).

一方, 体内 $\mathrm{N}$ 濃度の上昇は根部 $\mathrm{N} \%$ をき上げ る。それと葉面積增による茎重/葉面積比 $(\mathrm{C} / \mathrm{F})$ の低下との 2 要因は根の呼吸速度を対照区よりも高 
く維持する (5 式および第 4 表)。この根部呼吸速 度の促進は，第 5 図に示したとおり $\Delta \mathrm{N} / \Delta \mathrm{W}$ 比を 高めることにより， $\mathrm{N}$ 吸収量 $(\Delta \mathrm{N})$ の増加を促し て，体内 $\mathrm{N}$ 濃度を高く保持することができた。

弱光下で生長した葉は厚さが薄くなり，光補償点 が低下 ${ }^{1,2,7)}$ することが一般にいわれているが，本実 験では SLA の増大による補償点の低下は明らかで はなく，むしろ光合成速度の上昇によって光補償点 が低下することを認めた（第 1 図，第 4 図).

ここで注目しなければならぬのは，遮光処理によ つて体内 $\mathrm{N}$ 濃度が上昇し，かつ葉面積が増加して も，多くの区に拈いて個体暗呼吸速度が対照区より も増大しない点である（第6表）。この原因として あげることのできるのは（3）式の内容である。つ まり，体内 $\mathrm{N}$ 濃度上昇の反映として葉身 $\mathrm{N} \%$ が上 昇するが，これは暗呼吸を増加させる方向に作用す る $\left(r=0.568^{* *}\right)$. しかし, 葉面積の増加は $\mathrm{C} / \mathrm{F}$ 值 を低下させ，これが暗呼吸速度を低下させる方向に 作用するのである。ちなみに（3）式を標準化した とき葉身 N\%（NL）の標準偏回㷌係数は 1.399 で

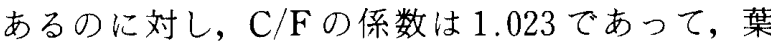
身 N\%の増加によりもたらされる呼吸増をかなり 強く打ち消すのである。

穂数がほぼ決定された段階で，かつ葉面積の拡大 が可能な場合における弱光条件のもとでは，水稲は その個体光合成能力を $\mathrm{Pg}$ と Fの 2 要因でもって高 める方向に調節能力が作用して，環境に順㐫するこ とがわかった。しかも，それは暗呼吸量の増大をも たらさないので乾物生産能力を効率よく高める。こ の高められた能力は，弱光条件後に晴天に恵まれた 場合に有効に発揮されるにちがいない. ただし，本 実験の場合は $50 \%$ の遮光条件下で, 個体光合成能 力を対象として得られた結果である。同様の処理で 遮光率が $50 \%$ 以上となると個葉光合成速度の低下 と，下葉の枯れ上がりのために弱光への調節機構が 発動しないことが認められている12)ので, 常に遮 光程度を念頭におくべきではあるが，水稲は軽度の 弱光条件に扔かれたとき個体光合成能力を強化する という方向に調節機能を発揮すると結論できる。

最後に品種特性に触れておきたい，遮光処理（S - II，III）でN吸収が促進される日本晴は, 群落条 件では過繁茂となる懸念がある。また，分げつ期間 の山あげ処理 $(\mathrm{Y}-\mathrm{I})$ により著しく $\mathrm{N}$ 吸収の低下 をみる日本晴は, 中山間部では穂数の確保が困難で あって，この品種が平坦部むきとして扱われている
所以の一つであろう。当地で中山間部むき品種とさ れているアキヒカリは遮光あるいは山あげによって $\mathrm{N}$ 吸収量の低下が他品種よりも著しい(第 1 表)。 この特性が，アキヒカリをして中山間部で安定した 作柄を示す品種として位置づけていると考えられ る、コシヒ力りは， $\mathrm{N}$ 吸収の面からみるとアキヒ カリに似た傾向を持つ。しかし，幼穂形成期から登 熟初期における遮光処理（S-II）によりN吸収が 促進されている。これは，節間伸長を促して倒伏に 至る危険性を示唆するものである。

\section{引用文献}

1. Björkman, O. and P. Holmgren 1963. Adaptability of the photosynthetic apparatus to light intensity in ecotypes from exposed and shaded habitats. Physiol. Plant. 16: 889-914.

2. - 1966. Photosynthetic adaptation to light intensity in plants native to shaded and exposed habitats. Physiol. Plant. 19: 854889

3. Burnside, C.A. and R.H. Böhning 1957. The effect of prolonged shading on the light saturation curves of apparent photosynthesis in sun plants. Plant Physiol. $32: 61-63$.

4. 長南信雄 1967. 禾殻類の葉に抢ける同化組織に関す る研究. 第 4 報 遮光処理における水稲の葉肉の構造 変化. 日作紀 36:297-301.

5. Iwaki, H. 1958. The influence of density on the dry matter production of Fagopyrum esculentum. Jap. J. Bot. $16: 210-226$.

6. 川田信一郎・鄭 元一 1978. 水稲根の根毛形成など に対する剪葉, 遮光および養分の葉面散布の影響. 日 作紀 47: 312-317.

7. ルンデゴルド，H. 1925. 植物実験生態学 門司正三・ 山根銀五郎・宝明欣二共訳, 1964. 岩波書店, 東京. 40, $79-80$.

8. 村田吉男 1961. 水稲の光合成とその栽培学的意義に 関する研究. 農技研報 D9 : 1-169.

9. 大島正男・村山 登 1960. 水稲の窒素栄養に関する る研究. [1] 窒素栄養を異にする水稲の生育各期に おける遮光の影響. 農技研報 B10:1-36.

10. 太田保夫 - 山田 登・加美佐郷 - 田島克己 - 舟山兼三 郎 1958. 水稲の登熟に関する研究. 第 2 報 登熟に 対する遮光の影響. 日作紀 27:196-200.

11. 佐藤 庚 1970 . 水稲葉の光合成におよぼす環境の影 響. 日作紀 $39: 370-375$.

12. 清水 強・津野幸人 1958. 主要作物の収量予測に関 する研究. IV. 水稲の乾物生産と日射量との関係並び に弱光に対する適応機構について.日作紀 27：168一 170.

13. 菅原友太 1942 . 水稲の生育並に含有成分に對する日 射及水素イオン濃度の影響. 日作紀 14:171-181.

14. Tatsumi, J. and Y. Kono 1980. Effects of shading 
on respiration and ammonium uptake of rice roots. - comparison of activity in roots from different nodes-. Japan. Jour. Crop Sci. 49 : 6674 .

15. - 1980. Nitrogen uptake and transport by the intact root system of rice plants. - comparison of the activity in roots from differentt nodes--. Japan. Jour. Crop Sci. $49: 349$ -358 .

16. 巽 二郎・河野恭広 1983. 地上部の遮光が水稲根系 の $\alpha$-ナフチルアミン酸化力に及ぽす影響. 日作紀
$52: 104-105$.

17. 津野幸人・鳥生誠二 1987 . 水稲根の呼吸阻害が光合 成作用に及ほすす影響. 日作紀 $56: 512-520$.

18. 一山口武視 1987. 水稲光合成の高温低下現 象と根の呼吸速度との関係ならびに根の呼吸速度に 関与する要因の解析. 日作紀 $56: 536-546$.

19. 内田直次・和田義春・村田吉男 1980. 作物の葉にお ける光合成機能の発達と衰退に関する研究. 第 3 報 イネ葉の衰退過程に及ほす光・温度の影響. 日作紀 49 (別 1)：127-128. 